\title{
LIMITED ENGLISH-PROFICIENT STUDENTS: ANALYSIS OF SUBJECTIVE EXPERIENCES
}

\author{
Diana Karanauskienė, Asta Lileikienė, Lina Danilevičienė \\ Lithuanian Sports University, Kaunas, Lithuania
}

\begin{abstract}
Background. Many long-term adolescent and adult learners experience persistent academic underachievement in English in spite of many years of schooling. Students pertaining A2 level can be classified as Limited EnglishProficient Learners who have not acquired English proficiency as required by the university, state and European guidelines. Research aim was to analyse the perceptions of underachieving students of reasons of their failure to gain English language proficiency of the required level aiming at increasing the knowledge on the problem and providing possible solutions for improvement.

Methods. Participants' perceptions of their underachievement reasons were elicited through individual unstructured in-depth interviews. Data analysis occurred concurrently with data collection using grounded theory as a method for analysing the data. Member checks with several research participants, reflexive journaling and peer debriefing were also utilized to ensure trustworthiness of the study.

Results. The examination of interview transcripts revealed two big themes concerning the students' underachievement in the English language: internal and external causes for being limited English-proficient learner. External causes were conditions for learning English at school and at the university: poor learning in primary grades, underestimated value of knowing and learning English at school, inadequate conditions for informal learning, and poor organization of English lessons. University factors mentioned were too few contact hours for English classes, inconvenient time-table, and lack of time due to other activities. Internal factors were fear to look unacceptable (resulting in the inactivity in the classes), lack of self-confidence, too much self-criticism, laziness, procrastination, finding faults with others, inadequate perception of the course, poor attitudes towards the course, lack of internal motivation, rating the module of English as a second-rate course, not knowing how to learn the language, and, what is most important, absence of self-study skills.

Conclusions. Internal factors conditioning underachievement in the English language proved to be much more important than the external ones. Poor self-esteem, lack of motivation and poor attitudes towards the course suggest the need of the individualization of teaching/learning and psychological counselling. Lack of self-study skills can predict poor academic achievements in other university courses, which could result in drop-outs. This suggests the need of coaching students in learning skills. The collected data show that the teacher also plays a crucial role in language learning, however, the wider societal, cultural and psychological context should be articulated in further possible research as well. Study programmes at tertiary level should be designed to encourage both internal and external motivation of students to study foreign languages as an indispensable factor for developing a full-rate personality.
\end{abstract}

Keywords: limited English - proficient learners, qualitative research, underachievement.

\section{INTRODUCTION}

$\mathrm{M}$ any long-term adolescent and adult learners experience persistent academic underachievement in English in spite of many years of schooling. Underachievers exhibit a severe discrepancy between expected achievement (as measured by standardized achievement scores or cognitive as well as intellectual ability assessment) and actual achievement (as measured by class grades 
and teacher evaluations) (Reis \& McCoach, 2002). At the college level, underachievement stems from either underprepared students or students who do not perform to expected standards (Bailey, Hughes, \& Karp, 2003; Nelson, 1998). Haycock and Huang (2001) found that nearly $50 \%$ of college students were not academically prepared.

Students pertaining A2 level can be classified as Limited English-Proficient Learners (Won \& Shernaz, 2014) who have not acquired English proficiency as required by the university, state and European guidelines. In the countries where students cannot use their own language to study university subjects academic underachievement in the English language usually results in undesirable educational outcomes, including low engagement, high retention and drop-out rates.

The academic achievements of Limited English-Proficient (LEP) students have long been a major educational concern in many countries because students in many non-English speaking countries have to be able to use English as a tool for learning subject matter at school or university. In the countries that English is not spoken as the mother tongue, programs in university education are targeted for foreign language learning (FLL) - which involves learning the target language in academic settings without regularly interacting with the target language community (typical European FLL environment). Hashemi (2011) suggests that students' weakness in English language learning is due to the differences of social contexts as well as cultural environments in different countries. Often, LEP students become proficient in communication skills; however, they encounter difficulties understanding and completing tasks in the more cognitively-demanding English language needed for successful performance in academic subjects (Lewelling, 1991).

Little research has been conducted on the issues relating to underachieving students' academic challenges. Although learners are the focus of the improvement of the study quality, their opinions are insufficiently taken into consideration. Students' academic performance may be closely related to how they perceive their studies and difficulties they encounter. Our understanding of the problem can be increased by students' educational experiences. Thus, our research question was as follows: what are underachieving students' perceptions of reasons of their failure to gain English language proficiency of the required level? Research aim was to analyse the perceptions of underachieving students of reasons of their failure to gain English language proficiency of the required level aiming at increasing the knowledge on the problem and providing possible solutions for improvement.

\section{METHODS}

Data collection. Data were collected in the spring semester of 2015. Participants' perceptions of their underachievement reasons were elicited through individual unstructured in-depth interviews. After explaining the purpose of the study and receiving the students' agreement to participate in the research, students were asked to reflect on the question: Why don't I succeed in learning English? Students were given no orientating questions; they were only encouraged to expand on the topic by short stimulating phrases (OK, anything else, etc.)

Research participants were students from two Lithuanian universities specializing in sport, physical fitness, health sciences and law. They were selected using the Criterion sampling strategy (participants were chosen because they had the particular features, characteristics and specific experiences). All in all, 54 participants were interviewed. The general principle that guided the sample size was the saturation of data, i.e. the redundancy of the further data obtained. Each interview lasted from five to 15 minutes. Contextual influences were considered as well.

Research participants were allowed to speak in their native (Lithuanian) language so that they did not have difficulties in providing genuine thoughts. The translation of the participants' responses and its linguistic validation were carried out by all the authors of the present research paper. The linguistic validation process consisted of three phases: forward translation (form Lithuanian into English), backward translation (from English to Lithuanian), and the preparation of the English version of transcripts (comparisons of both Lithuanian variants making the necessary amendments in the English version of the interview transcripts).

Data processing. Data analysis occurred concurrently with data collection using grounded theory as a method for analysing the data (Mills, Bonner, \& Francis, 2006; Pitney \& Parker, 2009). 
Transcribed data were divided into meaningful units with descriptive labels or categories, and categories that emerged from data were clustered into themes. Categories and themes were adjusted as data continued to be gathered and analysed.

Triangulation was used to ensure that the findings accurately reflected the situation. Member checks with several research participants, reflexive journaling and peer debriefing (with seven randomly chosen English language teachers from four Lithuanian universities, who were also given the same question) were also utilized to ensure trustworthiness of the study (Pitney \& Parker, 2009).

\section{RESULTS}

The initial examination of interview transcripts revealed two big themes concerning the students' underachievement in the English language: internal and external causes for being limited English-proficient learner. Internal causes are certain personal qualities that might have affected students' learning achievements (poor self-esteem, motivation attitudes, self-discipline, etc.). External causes mentioned were conditions for learning English at school and at the university. The categories and subcategories which emerged from the data together with examples from the transcripts as illustrations are given in Tables 1 and 2 .

Table 1. Internal causes of underachievement in English

\begin{tabular}{|c|c|c|}
\hline Category & Subcategory & Illustrations \\
\hline \multirow{3}{*}{ Poor self-esteem } & $\begin{array}{l}\text { Fear to look } \\
\text { unacceptable }\end{array}$ & $\begin{array}{l}\text { "I am afraid to say a word not to look stupid" } \\
\text { "my pronunciation is bad, and I am afraid to speak because I don't want to } \\
\text { be humiliated" } \\
\text { "I become nervous and stressed when I have to show my knowledge, so I fail" }\end{array}$ \\
\hline & $\begin{array}{c}\text { Lack of } \\
\text { self-confidence }\end{array}$ & $\begin{array}{l}\text { "I have very poor memory and I will never be able to memorize things" } \\
\text { "I am not good at many other courses" } \\
\text { "I don't have a talent for languages" } \\
\text { "I don't have the fundamentals of the language" } \\
\text { "I am afraid to speak in front of the class because I think I will fail" } \\
\text { "I can understand something in the classroom, but I don't understand } \\
\text { anything when I have to do my homework" }\end{array}$ \\
\hline & $\begin{array}{c}\text { Too much } \\
\text { self-criticism }\end{array}$ & $\begin{array}{l}\text { "I am very self-critical and always unhappy with my learning outcomes" } \\
\text { "I believe I have very poor memory" } \\
\text { "I feel discomfort because I am always worse than others" } \\
\text { "I am not good at all languages, including Lithuanian" }\end{array}$ \\
\hline \multirow[b]{3}{*}{ Poor self-discipline } & Laziness & $\begin{array}{l}\text { "I learnt to be lazy at school and I am still lazy now" } \\
\text { "all students are lazy including me" } \\
\text { "I cheated during English tests" } \\
\text { "I didn't learn the language at school and now I have no will-power to } \\
\text { change the situation for the better" }\end{array}$ \\
\hline & Procrastination & $\begin{array}{l}\text { "I always delay learning English because I want to do what is more } \\
\text { interesting to me" } \\
\text { "learning English takes too much time, so often I don't even start doing the } \\
\text { homework" } \\
\text { "first I spend my time learning more important subjects, then there remains } \\
\text { no time for English" }\end{array}$ \\
\hline & $\begin{array}{l}\text { Finding faults } \\
\text { with others }\end{array}$ & $\begin{array}{l}\text { "at school I had a very bad teacher who did not know how to teach" } \\
\text { "our teacher at school was rather permissive" } \\
\text { "I was learning English in a village school" } \\
\text { "I wasn't made to learn seriously, so I did not learn" } \\
\text { "my English teacher used to laugh at me whenever I made mistakes" } \\
\text { "the teacher at school did not help us improve" } \\
\text { "our teacher at school paid attention only to those who succeeded, others } \\
\text { could do whatever they wanted" } \\
\text { "life has been unfair to me: no strict parents, brothers or sisters who could } \\
\text { push me" } \\
\text { "Our psychology teacher has told us that a person cannot be good at all } \\
\text { things. I have a talent for other things. Not knowing English is in my genes" } \\
\text { "nobody has invented the most effective way how to achieve the necessary } \\
\text { level of English" }\end{array}$ \\
\hline
\end{tabular}


table 1 continued

\begin{tabular}{|c|c|c|}
\hline Category & Subcategory & Illustrations \\
\hline \multirow[b]{2}{*}{$\begin{array}{l}\text { Unfavourable } \\
\text { personal attitudes }\end{array}$} & $\begin{array}{l}\text { Inadequate perception } \\
\text { of the course }\end{array}$ & $\begin{array}{l}\text { "English is a very difficult language with too many tenses and complicated } \\
\text { constructions" } \\
\text { "too much learning by heart" } \\
\text { "learning English means memorizing many things, which is very hard" } \\
\text { "it is impossible to learn English without hiring a tutor" }\end{array}$ \\
\hline & $\begin{array}{l}\text { Poor attitudes towards } \\
\text { the course }\end{array}$ & $\begin{array}{l}\text { "I have hated English since the elementary grades" } \\
\text { "I don't have any wish to communicate in that language", } \\
\text { "I don't see chances to get interested in the English language" } \\
\text { "learning English is a waste of time, I need time for more serious courses" } \\
\text { "inappropriate attitude is the biggest obstacle" } \\
\text { "Students, including me, simply don't understand the purpose of self-study } \\
\text { hours. They think that at that time they are free, and usually they find jobs" }\end{array}$ \\
\hline \multirow[t]{2}{*}{$\begin{array}{l}\text { Poor } \\
\text { motivation }\end{array}$} & $\begin{array}{l}\text { Lack of internal } \\
\text { motivation }\end{array}$ & $\begin{array}{l}\text { "I don't need to know English at B2 level, I will never go abroad" } \\
\text { "I am sure I will not need English in my speciality, and I won't need } \\
\text { writing for sure" } \\
\text { "I don't have motivation to learn and I don't understand how to become } \\
\text { motivated" }\end{array}$ \\
\hline & $\begin{array}{l}\text { Rating the module of } \\
\text { English as a second-rate } \\
\text { course }\end{array}$ & $\begin{array}{l}\text { "at the university I am concentrated on the speciality courses, and English } \\
\text { is among the second-rate subjects" }\end{array}$ \\
\hline \multirow[t]{2}{*}{$\begin{array}{l}\text { Poor } \\
\text { learning skills }\end{array}$} & $\begin{array}{l}\text { Not knowing how to } \\
\text { learn the language }\end{array}$ & $\begin{array}{l}\text { "I never know what is not clear to me and that is why I always make silly } \\
\text { mistakes" } \\
\text { "I cannot understand what teachers want from me" } \\
\text { "I try to work hard in many ways (learning by heart, watching films, etc.), } \\
\text { but I feel that I am not improving" }\end{array}$ \\
\hline & $\begin{array}{l}\text { Absence of self-study } \\
\text { skills }\end{array}$ & $\begin{array}{l}\text { "at school nobody taught us how to work independently" } \\
\text { "So what that we have } 80 \text { percent of time for independent work. We don't } \\
\text { know how to use this time." }\end{array}$ \\
\hline
\end{tabular}

Table 2. External causes of underachievement in English

\begin{tabular}{|c|c|c|}
\hline Category & Subcategory & Illustrations \\
\hline \multirow{4}{*}{$\begin{array}{l}\text { Conditions for } \\
\text { learning English at } \\
\text { school }\end{array}$} & $\begin{array}{l}\text { Poor learning in } \\
\text { primary grades }\end{array}$ & $\begin{array}{l}\text { "I primary grades English was taught by unqualified teachers who were not } \\
\text { specialists" } \\
\text { "while I was in primary school, we had eight teachers in the period of three } \\
\text { years" }\end{array}$ \\
\hline & $\begin{array}{l}\text { Underestimated value } \\
\text { of knowing and learning } \\
\text { English at school }\end{array}$ & $\begin{array}{l}\text { "English received very little attention at school" } \\
\text { "teachers changed often, and they did not feel any responsibility for us" } \\
\text { "we had a good teacher at school who allowed us not to learn English, but } \\
\text { watch films or do something else" } \\
\text { "those who didn't plan to take an exam in English were allowed to do } \\
\text { nothing in the classroom" }\end{array}$ \\
\hline & $\begin{array}{l}\text { Inadequate conditions } \\
\text { for informal learning }\end{array}$ & $\begin{array}{l}\text { "in Lithuania there are no or very few opportunities to use the language } \\
\text { outside school or university" }\end{array}$ \\
\hline & $\begin{array}{l}\text { Poor organization of } \\
\text { English lessons }\end{array}$ & $\begin{array}{l}\text { "our English teacher was our class mistress, so English lessons were } \\
\text { intended for class matters, different problems in general, but not for } \\
\text { learning English" } \\
\text { "our teachers didn't come to English lessons or let us go", } \\
\text { "we never had any oral tasks, we only wrote exercises form the sixth till the } \\
\text { twelfth grade" } \\
\text { "the teacher spoke much in the classroom, and there was no time for us to } \\
\text { utter a word in English" }\end{array}$ \\
\hline \multirow{3}{*}{$\begin{array}{l}\text { Conditions for } \\
\text { learning English at the } \\
\text { university }\end{array}$} & Too few contact hours & $\begin{array}{l}\text { "it is impossible to reach B2 level in two semesters with so little contact time" } \\
\text { "two hours a week is not enough" }\end{array}$ \\
\hline & Inconvenient time-table & $\begin{array}{l}\text { "English classes are early in the morning, other lectures are in the middle } \\
\text { of the day, so sometimes we simply do not get up and go to English" }\end{array}$ \\
\hline & Lack of time & $\begin{array}{l}\text { "many students have jobs" } \\
\text { "sport takes too much time" } \\
\text { "too much time is planned for self-study, and in reality we don't have it" } \\
\text { "too many assignments in much more important study courses" } \\
\text { "I have to participate in extra-curricular activities" }\end{array}$ \\
\hline
\end{tabular}


Teachers' opinions:

- Poor learning skills, especially self-study skills.

- Inadequate attitudes and disposition.

- Poor motivation to learn English.

- Lack of self-confidence, "programming oneself for failure".

- Poor memory.

- Lack of communication skills.

- Poor writing skills.

\section{DISCUSSION}

Research results show that students' answers revealed two big groups of reasons to be limited English-proficient learners: internal and external. Internal causes are certain personal qualities that might have affected students' learning achievements (poor self-esteem, motivation attitudes, self-discipline, etc.).

External causes fall into two categories conditions for learning English at school and at the university. The most often mentioned school factors were poor learning in primary grades, underestimated value of knowing and learning English at school, inadequate conditions for informal learning, and poor organization of English lessons. University factors mentioned were too few contact hours for English classes, inconvenient time-table (for training sessions, great gaps in the timetable, and too early to get up in the morning), and lack of time due to other activities.

Discussions with English language teachers have shown that in Lithuanian universities, there are practically about one-fifth of students (in other fields than English Philology) underachieving in the English language, i.e. with A2 level of proficiency in the English language. It means that the majority of students who are successful in learning English have had the same favourable and unfavourable conditions at school and university: timetables, turnover of teachers, teachers' personality traits and teaching skills, etc. On the other hand, university teachers interviewed have not mentioned any external conditions (both at school and university) interfering with learning. Though research findings suggest that lack of motivation provided by teachers at school could have a negative impact on children's performance (Sousa, 2002), still it can be concluded that external causes are not of primary importance for the underachievement in the subject; at least they are not decisive.
Internal factors conditioning underachievement in the English language which were mentioned by students were fear to look unacceptable (resulting in the inactivity in the classes), lack of self-confidence, too much self-criticism, laziness, procrastination, finding faults with others, inadequate perception of the course, poor attitudes towards the course, lack of internal motivation, rating the module of English as a second-rate course, not knowing how to learn the language, and, what is most important, absence of self-study skills.

Chang (2010) indicated that reasons causing students' weakness for English language learning derived from learners' laziness, lack of efficiency of the school, and insufficient parents' promotions. Moreover, a survey into the internal causes of English language learning in students also found that students felt anxiety, they were afraid of making mistakes in the classes, failing in task accomplishment, as well as were ashamed of their pronunciation skills, which, consequently, caused the poor performance in learning languages (Khattak, Jamshed, Ahmad, \& Baig, 2011). In addition, the lack of practice outside the classroom (typical European FLL environment) leads to resulting low proficiency and failure of the majority of A2 level students, so that they did not feel they had as of yet mastered any aspect of the language.

If students are strongly motivated, they will enjoy learning the language; will need to learn the language and attempt to learn the language (Sakiroglu \& Dikilitas, 2012). At the university level emphasis should be put on designing study programmes of professional English or ESP (English for Special Purposes) which would motivate students to study English in their chosen field and the knowledge of which could help them become more competitive in a demanding labour market. Moreover, motivation has usually been considered to be the key concept in the learning of foreign language (Klimova, 2011). Therefore, students should eliminate the internal hindrances in their motivation as well as teachers have to help them improve the motivational beliefs and language learning strategies in order to find ways that reach to their academic achievement.

The modern university is a complex social organization. In today's world, universities, in particular those in the West, have increasingly become networked, informationalized, and commercialized, and tend to operate on a clock or chronologic time like a business or corporation, 
though their demands on individuals are often in real or chronoscopic time terms. Scheduled time gives people on a modern university campus their rhythm of life (Liao et al., 2013). In this context lack of skills for independent learning should be given much consideration. The benefits of knowing the English language are much more than just linguistic ones. There are social, psychological and cognitive advantages to being proficient in foreign language (Dewaele \& Thirtle, 2009). Knowing more languages has been linked to lower levels of communicative anxiety in different languages (Dewaele, Petrides, \& Furnham, 2008). It has also been linked to higher levels of creativity (Karkhurin, 2007) and a higher level of metalinguistic awareness (Kemp, 2007). Clearly, in today's globalised world it is, thus, an imperative for educators and teachers to address the issue of uptake of the English language urgently, and with the attention it deserves.

The results of the study show that there is no shortcut to the development of cognitive academic English language proficiency and to academic achievement in other subjects concurrently. It is a long-term process that initiates in even pre-school activities when a human personality starts to develop.

The limitation of the study is that the results are related to the contexts in which the study was carried out. Thus the transferability of the findings might be limited to similar settings, students or institutions of education. Absence of some factors causing low English language proficiency may suggest that they are not significant, or only that they were not mentioned and recorded at the time of the interviews. Certainly, the study is limited in time and space as it was conducted in one city of Lithuania. Besides, there are constant changes in the system of higher education in response to which some of the findings might be different as well.

For future research, the focus may be put on the differences in students' English proficiency before and after graduation from the university to measure progress in students' English proficiency and the efficacy of study programmes at the universities.

\section{CONCLUSIONS}

1. Internal factors conditioning underachievement in the English language proved to be much more important than the external ones.

2. Poor self-esteem, lack of motivation and poor attitudes towards the course suggest the need of the individualization of teaching/learning and psychological counselling.

3. Lack of self-study skills can predict poor academic achievements in other university courses, which could result in drop-outs. This suggests the need of coaching students in learning skills.

4. The collected data show that the teacher also plays a crucial role in language learning, however, the wider societal, cultural and psychological context should be articulated in further possible research as well.

5. Study programmes at tertiary level should be designed to encourage both internal and external motivation of students to study foreign languages as an indispensable factor for developing a full-rate personality.

\section{REFERENCES}

Bailey, T. R., Hughes, K. L., \& Karp, M. M. (2003). Dual enrolment programs: Easing transitions from high school to college (CCRC Brief, ERIC Document Reproduction Service No. ED475805). New York: Community College Research Center.

Chang, Y. P. (2010). A Study of EFL college students' self-handicapping and English performance. ProcediaSocial and Behavioral Sciences, 2(2), 2006-2010.

Dewaele, J., Petrides, K. V., \& Furnham, A. (2008). The effects of trait emotional intelligence and sociobiographical variables on communicative anxiety and foreign language anxiety among adult multilinguals: A review and empirical investigation. Language Learning, 58(4), 91-60.
Dewaele, J., \& Thirtle, H. (2009). Why do some young learners drop foreign languages? A focus on learnerinternal variables. International Journal of Bilingual Education \& Bilingualism, 12(6), 635-649.

Hashemi, M. (2011). Language stress and anxiety among the English language learners. Procedia - Social and Behavioral Sciences, 30(0), 1811-1816. http://dx.doi. org/10.1016/j.sbspro.2011.10.349

Haycock, K., \& Huang, S. (2001). Are today's high school graduates ready? Thinking K-16, 5, 3-17.

Karkhurin, A. V. (2007). The role of cross-linguistic and cross-cultural experiences in bilinguals' divergent thinking. In I. Kecskes \& L. Albertazzi (Eds.), Cognitive 
aspects of bilingualism (pp. 175-210). Berlin, Germany: Springer.

Kemp, C. (2007). Strategic processing in grammar learning: Do multilinguals use more strategies? International Journal of Multilingualism, 4, 241-61.

Khattak, Z. I., Jamshed, T., Ahmad, A., \& Baig, M. N. (2011). An investigation into the causes of English language learning anxiety in students at AWKUM. Procedia - Social and Behavioral Sciences, 15(0), 1600-1604.

Klimova, B. F. (2011). Motivation for learning English at a university level. Procedia - Social and Behavioral Sciences, 15(0), 2599-2603.

Lewelling, V. W. (1991). Academic achievement in a second language. ERIC Digest. Washington, DC: ERIC/ CLL.

Liao, T. F., Beckman, J., Marzolph, E., Riederer, C., Sayler, J., \& Schmelkin, L. (2013). The social definition of time for university students. Time \& Society, 22(1), 119-151. doi: 10.1177/0961463X11404385

Mills, J., Bonner, A., \& Francis, K. (2006). The development of constructivist grounded theory. International Journal of Qualitative Methods, 5(1),
Article 3. Retrieved from http://www.ualberta.ca/ iiqm/ backissues/5_1/pdf/mills.pdf

Nelson, R. R. (1998). Achievement difficulties for the academically gifted. Journal of College Reading and Learning, 28, 117-123.

Pitney, W. A., \& Parker, J. (2009). Qualitative research in physical activity and the health professions. USA: Human Kinetics.

Reis, S. M., \& McCoach, D. B. (2000). The Underachievement of gifted students: What do we know and where do we go? Gifted Child Quarterly, 44(3), 152-170.

Sakiroglu, B., \& Dikilitas, K. (2012). Language learning motivation of Turkish tertiary level EFL students. Procedia - Social and Behavioral Sciences, $46(0), \quad 3215-3219$. doi: http://dx.doi.org/10.1016/j. sbspro.2012.06.039

Sousa, D. A. (2003). How the gifted brain learns. California: Corwin Press.

Won, G. K., \& Shernaz, B. G. (2014). Long-term English language learners' perceptions of their language and academic learning experiences. Remedial and Special Education, 35(5), 300-312. doi: $10.1177 / 0741932514525047$ 